\title{
Article \\ Contingent Effect of Board Gender Diversity on Performance in Emerging Markets: Evidence from the Egyptian Revolution
}

\author{
Melsa Ararat ${ }^{1}$, Moataz El-Helaly ${ }^{2}$, Alan Lowe ${ }^{3}$ and Nermeen Shehata ${ }^{2, *(D)}$ \\ 1 Sabanci Business School Orta Mahalle, Sabanci University, Tuzla, Istanbul 34956, Turkey; \\ melsa.ararat@connect.sabanciuniv.edu \\ 2 School of Business, The American University in Cairo, AUC Avenue, P.O. Box 74, New Cairo 11835, Egypt; \\ m.elhelaly@aucegypt.edu \\ 3 College of Business and Law, RMIT University, 124 La Trobe Street, Melbourne, VIC 3000, Australia; \\ alan.lowe@rmit.edu.au \\ * Correspondence: n.shehata@aucegypt.edu
}

Citation: Ararat, Melsa, Moataz El-Helaly, Alan Lowe, and Nermeen Shehata. 2021. Contingent Effect of Board Gender Diversity on Performance in Emerging Markets: Evidence from the Egyptian Revolution. Journal of Risk and Financial Management 14: 538. https://doi.org/10.3390/ jrfm14110538

Academic Editor: Ştefan Cristian Gherghina

Received: 20 September 2021 Accepted: 5 November 2021 Published: 9 November 2021

Publisher's Note: MDPI stays neutral with regard to jurisdictional claims in published maps and institutional affiliations.

Copyright: (c) 2021 by the authors. Licensee MDPI, Basel, Switzerland. This article is an open access article distributed under the terms and conditions of the Creative Commons Attribution (CC BY) license (https:/ / creativecommons.org/licenses/by/ $4.0 /)$.
Abstract: The 2011 Egyptian revolution was associated with significant political and social upheaval, followed by societal changes and attempts by policymakers to reduce the marginalisation of women and promote their inclusion in the economy. Drawing on this background, the authors compare the effect of board gender diversity before and after the revolution. Results indicate that gender diversity in corporate boards is coupled with improvements in firm performance in the immediate post revolution phase. This evidence provides insights into the contextual factors related to diversity and performance relationship and supporting arguments for regulatory changes to further encourage women's representation on boards.

Keywords: corporate governance; boards of directors; Egypt; gender diversity; Egyptian Revolution

\section{Introduction}

In recent years, a number of countries have enacted hard or soft laws to increase the representation of women on corporate boards. Regulatory interventions of this type aim to address societal and labour concerns in addition to deficiencies in board oversight due to entrenchment. A subset of the regulatory changes has been focused on the diversity of the workforce designed particularly to address the evidence that women have experienced conscious or unconscious negative discrimination. Nevertheless, and despite the advances achieved, female representation in the boardroom remains far from desired levels. In this context, it is now past time to try to rectify the lack of board gender diversity (RegueraAlvarado et al. 2017).

The objective of this study is to highlight the advantages of board gender diversity from an economic point of view. This is achieved by assessing the presence of female directors on Egyptian corporate boards around the 2011 revolution, and the changes in the impact of this presence on financial performance alongside with the changes in the social and economic context that have affected the perceptions around the value of women's contributions. This inquiry is motivated by two main drivers. First, investigating the contribution of board gender diversity to firm performance in an understudied but important country. Second, examining whether the presence of females in corporate boards may impact firm performance especially during times of uncertainty and economic instability.

Gender diversity is a popular field of inquiry. On one hand, an analysis of the existing literature in this field shows that several studies, especially empirical quantitative studies, have supported the argument that gender diversity in boards is typically associated with positive outcomes (Post and Byron 2015). However, on the other hand, there is also evidence that gender diversity is neutral for firm performance or may even be associated with negative outcomes (Adams and Ferreira 2009; Özbilgin et al. 2016). According to 
Özbilgin et al. (2016), the mixed results, at least partially, have been attributed to the fact that the outcomes of diversity cannot necessarily be explained through a simple quantitative model that examines correlations or causal relationships with other variables of interest. Moreover, there are several factors that change over time and across countries that could logically influence the effect of gender diversity on organisational outcomes, especially financial performance (Özbilgin et al. 2016).

Thus, it could be argued that providing evidence that the presence of women on corporate boards makes a difference and is associated with positive outcomes is quite challenging. This is especially the case for emerging markets where research outcomes on the role of board gender diversity deviates from developed markets due to market inefficiencies and institutional factors that cannot be easily operationalised in empirical studies (Ararat et al. 2021). Adams and Ferreira (2009) show that the impact of board monitoring on performance is most valuable in countries where there are weak corporate governance systems. As such we would expect women directors to influence monitoring and firm performance much more in countries where there is weak corporate governance and less corporate transparency. Regardless of the significant improvements that were achieved in Egypt related to corporate governance prior to the 2011 revolution, other challenges like corporate transparency and oversight in the accounting and auditing professions have remained (OECD 2010).

Therefore, this paper seeks to provide evidence on the positive impact of board gender diversity on firm performance in an emerging market to show that, in addition to the positive role of gender diversity documented by prior studies, gender diversity could be even more desirable during times of turmoil and uncertainty.

This study focuses the inquiry on the Egyptian Arab Spring revolution of 2011, as this setting facilitates investigation of the effect of board gender diversity from a unique angle. The context of the study represents a setting in which there had been an exogenous shock that changed the status of women in Egypt and reduced the extent to which they are marginalised, yet simultaneously entailed significant political and social changes throughout the country.

This study seeks to contribute to extant literature by providing evidence that may be persuasive, in the eyes of certain non-academic audiences, with regard to making more room for women on corporate boards. Specifically, the authors observe how the presence of women appears to have a different and more positive effect on firm performance during periods of political instability and economic uncertainty, while values of equality and justice are on the rise. It has also been reported that in the post-2011 revolution period, the representation of female directors on boards led to significantly higher firm performance, while no observable relationship is found between board gender diversity and firm performance before the revolution. The results also show that the positive effect of national diversity on firm performance diminished after the revolution, and foreign directors whose presence was associated with better performance were no longer effective. These two results together suggest that an enabling context is an important mediator in the relationship between gender diversity and firm performance.

The contribution of this study is two-fold. First, the authors engage in the discourse about women's inclusion in corporate boards and provide quantitative evidence on how women's presence in corporate boards could make a difference to firm performance in an enabling environment. Second, contrary to the mainstream of research investigating the relationship between board gender diversity and firm performance in regular circumstances or states of equilibrium, this paper extends the scarce, yet growing, evidence base on the role of gender diversity in contexts of political, social and/or economic turmoil and uncertainty (Farag and Mallin 2017). The authors argue that one key pillar that supports the originality of this study is driven by the exogenous shock employed in the research design, which helps in drawing comparative conclusions about two different time periods.

The remainder of this paper is organised as follows: Section 2 presents a detailed description of the Egyptian context, including the political scene, the role of women 
in Egypt and the norms of corporate governance in the periods before and after the 2011 revolution. Section 3 provides an overview of literature on the board diversity-firm performance relationship, and then discusses the role of macroeconomic and political forces in shaping the corporate governance environment. Section 4 discusses the research design, data and sample; Section 5 presents the analysis and empirical results; and finally, Section 6 concludes the paper.

\section{The Case in Context: Egypt}

\subsection{The Political Context}

It has been argued that a number of significant factors contributed to the dissatisfaction and unrest that preceded the Arab Spring in Egypt. These included socio-economic issues such as inequality, poverty, a lack of social programmes, poor systems of government and extreme levels of corruption or personal favouritism (Acemoglu et al. 2018). By 2010, protests of various hues had broken out in a number of Arab countries (Ottaway and Hamzawy 2011). In late 2010 and early 2011, semi-permanent camps had been established by ordinary people fervently protesting the existing socio-economic and political status quo, which were widely seen to benefit a relatively narrow group of families and individuals. This preferential treatment was also seen as extending to a number of large Egyptian firms with ties to the regime (Acemoglu et al. 2018; Choukeir 2013). The peaceful demonstrations began in January 2011 and continued until the president (Mubarak) stepped down on 12 February 2011 (Aboud and Diab 2019).

The "January Revolution" of 2011 was followed by a period of clear political instability. The country was initially managed by the military (2011-2012), followed by an Islamistmajority parliament and presidency. Islamists, and the Muslim Brotherhood (MB) party in particular, then ruled the country for one year (2012-2013). In June 2013 the Muslim Brotherhood and their president were deposed after only one year of ruling. Abdel-Fattah El Sisi then began ruling the country (Aboud and Diab 2019) and remains in power as of 2021. In early 2014 the country entered into a more settled period, though still under military rule. This period was characterised by challenges in coping with a budget deficit running at over $12 \%$ of gross domestic product (GDP), and debt levels reaching $95 \%$ of GDP, but relative stability. The World Bank approved a \$3 billion, three-year loan at the end of 2015. This may have played an instrumental role in restoring investor confidence in foreign exchange markets and improving the deficit. During this period, the economy also relied heavily on support from the Gulf States (The Economist 2016).

In common with earlier international support for developing nations, the World Bank loan was accompanied by a larger, $\$ 12$ billion, loan from the International Monetary Fund (IMF). This IMF loan was subject to conditions that required the implementation of strict neoliberal-inspired reform, including tax reform (notably a new value-added tax), the elimination of energy subsidies and allowing the Egyptian currency to float. At the political and economic level, the IMF's seal of approval on a programme of reforms restored investor confidence. Egypt's Eurobond of $\$ 4$ billion was oversubscribed by three times (Saleh 2017). The Ministry of Finance attributed the high demand for Egypt's Eurobond to the great confidence in the Egyptian economic reform programme (Reuters 2018).

The period of turmoil around the revolution has been assessed as extending over in excess of three years, from February 2011 to June 2014 (New York Times 2014). Therefore, the authors selected 2011-2014 as a recognised period of uncertainty ending in 2015. While Egypt moved up three places to 116 out of 140 economies in the World Economic Forum's (WEF) Global Competitiveness Index, and corruption was reported to have declined substantially, youth unemployment and poverty continued to contribute to Egypt's fragility (WEF 2017).

\subsection{Women in Egypt}

As shown in Table 1, women represent only about a quarter of the Egyptian workforce, with minimal participation in industry. Egypt was ranked 123 out of 144 countries in 
the "Gender Gap Report" in 2011 (WEF 2017). Rising inequality and lack of social justice and discontent about the role of women have been a permanent concern for the society. The revolution's main slogan of "bread, freedom, and social justice" encapsulated the call for equal opportunities for all-including women, who played an influential role at the forefront of the 2011 revolution (Mostafa 2015; Naber 2011).

Table 1. Female presence in various positions.

\begin{tabular}{|c|c|c|c|c|c|c|c|}
\hline Year & $\begin{array}{c}\text { Population, } \\
\text { Female } \\
\text { (\% of Total) }\end{array}$ & $\begin{array}{c}\text { Labour Force, } \\
\text { Female } \\
\text { (\% of Total } \\
\text { Labour Force) }\end{array}$ & $\begin{array}{c}\text { Employment } \\
\text { in Services, } \\
\text { Female } \\
\text { (\% of Female } \\
\text { Employment) }\end{array}$ & $\begin{array}{c}\text { Employment } \\
\text { in Industry, } \\
\text { Female } \\
\text { (\% of Female } \\
\text { Employment) }\end{array}$ & $\begin{array}{c}\text { Employers, } \\
\text { Female } \\
\text { (\% of Female } \\
\text { Employment) }\end{array}$ & $\begin{array}{c}\text { Non- } \\
\text { Discrimination } \\
\text { Clause Mentions } \\
\text { Gender in the } \\
\text { Constitution } \\
(1=\text { yes; } 0=\text { no })\end{array}$ & $\begin{array}{c}\text { Proportion of } \\
\text { Seats Held by } \\
\text { Women in the } \\
\text { National } \\
\text { Parliament (\%) }\end{array}$ \\
\hline 2005 & 49.6 & 21.2 & 48.4 & 5.0 & 3.8 & - & 2.0 \\
\hline 2006 & 49.6 & 21.9 & 50.6 & 6.0 & 2.8 & - & 2.0 \\
\hline 2007 & 49.6 & 23.6 & 47.2 & 6.2 & 3.4 & - & 1.8 \\
\hline 2008 & 49.6 & 23.6 & 48.8 & 5.6 & - & - & 1.8 \\
\hline 2009 & 49.5 & 23.8 & 48.8 & 5.1 & 3.8 & 0 & 1.8 \\
\hline 2010 & 49.5 & 24.0 & 51.2 & 5.9 & 3.1 & - & 12.7 \\
\hline 2011 & 49.5 & 24.0 & 51.5 & 5.1 & 3.2 & 0 & 2.0 \\
\hline 2012 & 49.5 & 24.1 & 56.9 & 5.5 & 2.8 & - & 2.0 \\
\hline 2013 & 49.5 & 24.1 & 52.1 & 5.0 & 2.2 & 0 & - \\
\hline 2014 & 49.5 & 24.1 & 51.8 & 4.9 & 2.2 & - & - \\
\hline 2015 & 49.5 & 23.1 & 54.2 & 5.6 & 2.0 & 1 & - \\
\hline 2016 & 49.4 & 23.0 & 55.4 & 6.1 & 2.3 & - & 14.9 \\
\hline 2017 & 49.4 & 23.1 & 56.5 & 6.0 & 2.3 & 1 & 14.9 \\
\hline
\end{tabular}

This table provides statistics on the presence of women in various positions in Egypt before and after the 2011 revolution. Source: World World Bank (2017). Percentages are rounded to the nearest decimal. '-' denotes missing data.

Socially defined gender roles change slowly. The Egyptians have significant patriarchal attitudes towards gender roles. $86.8 \%$ and $76.7 \%$ of men and women in Egypt, respectively, believe that the basic role for women is to take care of the home (UN Women and Promundo 2017). A strong majority of men (90\%) and $58 \%$ of women say that final decisions about domestic life should be made by the man (UN Women and Promundo 2017). When it comes to leadership, around two-thirds of the men oppose to the prominence of women in political life (UN Women and Promundo 2017). According to the same report "... religion was particularly important to many men in defining the 'rightful' attributes of men and women". The first key recommendation of the report is to engage key sources of social influence, including religious, political and community leaders, to change patriarchal social norms.

A more prominent role for women was exemplified in unprecedented social changes following the revolution. Several female activists, politicians and university professors were frequently featured and interviewed in the media and on public TV shows. Moreover, in 2011, Buthayna Kamel became the first woman to announce her run in the 2012 presidential election. In the November 2011-January 2012 elections, only eight women were elected as members (less than $2 \%$ ) of Parliament. Until 2015, the Egyptian constitution had no quotas for the political representation of women (Hasan 2015).

The National Council for Women issued a strategy for the empowerment of Egyptian women in 2017. The first paragraph of the report's introduction states that:

"Transformations witnessed by the Egyptian society since 2011, Egypt is progressing confidently towards building a new future for all the nation's sons and daughters. Serious efforts to truly empower the broader base of Egyptian women, ensure their full participation, and support the fulfilment of their full potential, contributes to the nation-building process and the achievement of sustainable development. Sustainable development entails a process of societal change that offers real and undiminished opportunities for all women to build their human capacities that would, in turn, widen their choices and enable their self-fulfilment and service of the nation." (National Council for Women 2017, p. 11).

As a result of changing norms, a non-discrimination clause first appeared in the constitution in 2015 (Table 1). Under the newly introduced electoral system, each political 
party running for elections was required to nominate at least one woman (Hasan 2015). In the first elected parliament under the presidency of Abdel-Fattah El Sisi, 89 women $(14.9 \%)$ were elected as members of parliament. Moreover, the last version of the Egyptian corporate governance code issued in 2016 was the only one that addressed board diversity by stating that "Guided by international best practices, the Board composition should ideally be made up of a diverse mix, unbiased to gender or faith." (EIoD 2016, p. 21). It should be noted that the first code in Egypt was issued in 2005. The code was amended in 2011 directly after the revolution, in March 2011, then the latest version was released in 2016. All versions of the CG code were issued on a comply/explain basis (Abdel-Meguid 2021).

Although the MB had full control over the political scene in Egypt for a period of less than a year (July 2012-June 2013), Egypt's ranking deteriorated immediately according to the Gender Gap Report (WEF 2017). However, religious and social conservatism did not take root in Egyptian society. The introduction of a non-discrimination clause in the 2015 constitution and a gender quota of $12 \%$ women in the national parliament signified a change in the number of women holding representative roles in government, reflecting the expectations of the society. The president was authorised to appoint a certain number of parliamentarians, which must include women. Of the 89 seats the president appointed 14 women (Al-Wahaidy 2017; El-Behary 2016). The percentage of seats held by women was $14.9 \%$ in 2015/16 - a huge increase from the $2 \%$ in 2011, preceding the introduction of the quota. ${ }^{1}$

These developments signify changes in perceptions of women's role in society, at least from the rule makers' perspective. According to one female parliamentarian, "new policies, new societal attitudes, new structures and new outlooks [are needed] for women's participation to become effective" (Fracolli 2017). This has also been reflected in the representation of women on boards. Figure 1 shows that the percentage of women on board steadily increased post-2011, suggesting that men stepped down to open spaces for women, and women were not just token additions to existing boards.

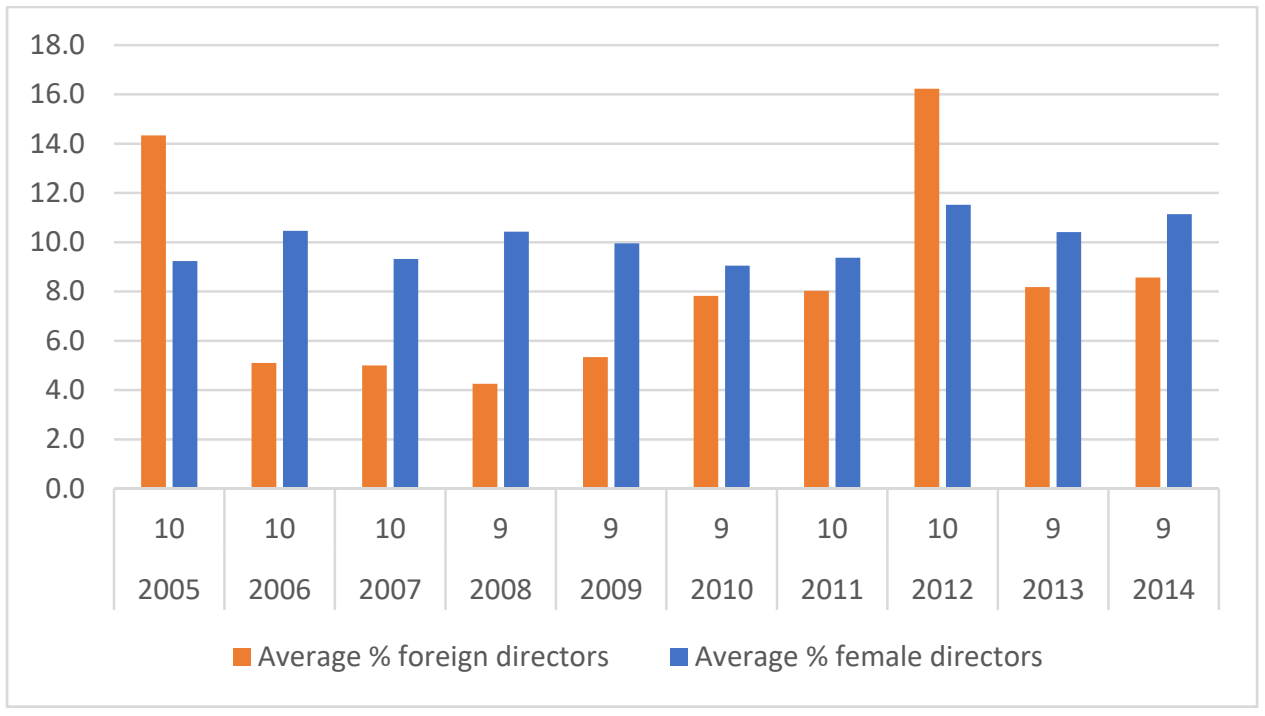

Figure 1. BOD diversity. This figure presents the average board size provided on the primary axis while the average percentage of female directors, and average percentage of foreign directors for the sample companies for 2005-2014 provided on the secondary axis.

In summary, the political and social upheaval witnessed in Egypt after the 2011 revolution was accompanied by significant changes in the role of women in society at large. In addition, there was clear indication that political leadership in the country was seeking to decrease the extent to which women were marginalised. This context of shock enables us to investigate how such a change in the role of women in society was echoed at the level of corporate boards and had an impact the acceptance of women in positions of 
authority. Additionally, assuming that women's inclusion in corporate boards increased subsequent to the revolution, findings that firm performance is positively impacted with such increases would provide persuasive evidence that women's inclusion in corporate boards is beneficial to firms when the contribution is encouraged.

\section{Prior Literature and Hypothesis}

\subsection{Corporate Governance and Board Diversity}

Women can contribute to firm performance through three channels. The first pertains to the differences between men and women in terms of individual characteristics, preferences and backgrounds (Adams and Ferreira 2009). For example, women's contributions to boards have been extensively discussed with respect to their greater socio-moral sensitivity and the added value it may represent for firms (Tremblay et al. 2016). It has been argued that women experience a greater sense of morality (Sinclair 1998) and mutual empowerment (Dillard and Reynolds 2008). Finally, the fact that women have been shown to differ from men in several aspects, are more risk averse then men and are more likely to propose less aggressive strategies represents one of the main arguments that links board gender diversity to the economic results of the firm (Reguera-Alvarado et al. 2017).

The second relates to diversity, since diverse teams make better decisions compared to homogenous teams, and a higher degree of gender diversity is likely to improve boards' decision-making quality (Kahane et al. 2013). Female directors are likely to bring different resources, add diversity to the boards' human capital, and help displace less productive male directors (Hermalin and Weisbach 2003). Prior studies have argued that greater gender diversity among board members creates richness of opinions and critical questioning, and that the outcomes generally reflect a greater consideration of moral concerns (Lau and Murninghan 1998). The third channel entails eliminating discrimination. If companies discriminate against women in director appointments, they are likely to experience a competitive disadvantage (Becker 1957).

While theoretically all channels suggest a positive association between board gender diversity and firm value and performance, empirical studies have revealed mixed results. Studies examining the effect of board gender diversity on firm value and performance have focused predominantly on developed markets, where capital markets are considered to be more efficient (Kirsch 2018).

Ahmadi et al. (2018) report a positive association between board gender diversity and firm performance in France. Adams and Ferreira (2009) showed that boards with higher levels of gender diversity can allocate more time to board monitoring but reported that the direction of the performance effect of gender quotas is contingent upon the quality of governance. They suggest that women can improve the governance of badly governed companies, but not that of companies that are already well governed. More recent research suggests that the quality of male directors increase when companies search for qualified female candidates when mandated by quotas (Ferreira et al. 2020). This literature has also tended to argue that gender diversity is more likely to be realised if firms value diversity (Van Knippenberg et al. 2007) - a point that is particularly important for the intended inquiry. On the impact of public opinion, Giannetti and Wang's (2021) recent research documents that public attention to gender equality is associated with an increase in presence of women on boards. Their findings further suggest that, during such periods, female board representation also generate higher abnormal announcement returns. (Carter et al. 2003; see also Cumming et al. 2015; Francoeur et al. 2008; Velthouse and Kandogan 2007) report that greater gender diversity enhances the independence of the board. On the other hand, several studies provide evidence on the negative association between gender diversity and firm performance. Adams and Ferreira (2009) found a negative relationship between the proportion of women on the board and firm performance in better governed companies. Similarly, Smith et al. (2006) documented a negative relationship between gender diversity and firm performance in a sample of Danish firms. 
Similarly, the boards' gender diversity research in emerging economies provides mixed evidence on the abovementioned relationship. One stream of the literature suggests that gender diversity may have a positive performance effect in emerging economies provided that women are professionally competent, and the power of controlling shareholders is contestable by independent directors (Ararat and Yurtoğlu 2021). Similarly, Mertzanis et al. (2019) find that in the MENA region board gender diversity has a significant positive effect on firm performance measured by ROA, whereas no effect is traced to Tobin's Q. This notion is also supported by the findings of Ramadan and Hassan (2021) who document a positive relationship between board gender diversity and firm efficiency in Egyptian listed firms. On the contrary, other studies provide evidence on negative consequences of gender diversity. Al-Yahyee et al. (2017) documented that female directors had a negative and significant influence on market risk disclosures in six Gulf Cooperation Council (GCC) countries. Also, in India, Oware and Mallikarjunappa (2021) found a negative association between gender diversity in boards and firm performance.

In summary as a recent meta study suggests, gender diversity in boards may have a positive influence on corporate performance but the relationship is contextual (Post and Byron 2015). This result is in line with some arguments that challenge findings based on the notion that the relationship between board diversity and firm performance is contingent on other factors, like culture, legal regulation, geographical context, and institutional factors. Therefore, the literature suggests a complex picture of diversity outcomes, rather than a simple linear relationship (Özbilgin et al. 2016).

\subsection{Hypothesis}

The relationship between diversity and financial performance is too complex to be explained by a simple linear relationship or through causal assumptions that might disregard internal and external factors that moderate the diversity-performance relationship (Özbilgin et al. 2016). Internal factors such as organisational strategy, and external factors represented by market and institutional factors and changes in the pressure shaped by those forces on organisations, even contribute further to the complexity of the relationship between diversity and performance. It is worth noting that little is known about whether the assumption that the representation of women on boards is associated with positive organisational outcomes holds in regions and times characterised by turmoil and uncertainty. In that vein, although existing evidence is rare, Farag and Mallin (2017) examined the influence of board diversity on bank performance in the aftermath of the global financial crisis. Their results showed that a critical mass of female representation on both the supervisory board and the board of directors may reduce banks' vulnerability to financial crisis. That said, the significant change in the status of women in Egypt after 2011, as well as the apparent attention given to increasing women's representation and inclusion on different fronts, offers a unique opportunity to generate broader knowledge of the impact of diversity.

Thus, the authors argue that, given the nature of the revolution, which represents a sudden change in both the status of women in Egypt and the internal and external factors that could affect the relationship between gender diversity and firm performance, examination of the relationship between the two variables in a context characterised by turmoil and upheaval, coupled with an increased role of women in social life, is warranted. Finally, given the currently limited evidence on whether gender diversity has a significant effect on firm performance during times of uncertainty, the authors assess whether such diversity has positive organisational outcomes during times of uncertainty. Thus, the hypothesis is as follows:

The relationship between boards' gender diversity and firm performance changed after the 2011 Egyptian Revolution, such that increased gender diversity enhanced firm performance. 


\section{Methodology, Data and Sample}

\subsection{Main Regression Model}

Studies on the impact of diversity on firm performance have provided evidence on the positive relationship between board gender diversity and firm performance; however, such studies have also noted that the results might be subject to endogeneity issues. Thus, observed differences in firm performance could have been caused by unobservable heterogeneity across firms, or observable determinants of firm performance that were omitted from the analysis (Nikolaev and Lent 2005). This problem can best be tackled via a natural experiment conducted in the context of an exogenous shock to board diversity itself (Wintoki et al. 2012). Such shocks include the introduction of legal quotas, and new regulations or listing rules that affect board structure. The Egyptian Revolution is used to represent an exogenous shock to the economic sectors that disrupted both political linkages and the relationship between board diversity and the financial performance of the companies studied. The authors' reasoning for focusing on this event is as follows: although political upheaval was not immediate, the revolution was unexpected, and its outcomes were not predictable. Moreover, the period that followed the revolution entailed several chaotic shifts in political (and, concurrently, economic) power. In such a setting, it would not be expected that firms have continuously optimised their board structures. Thus, this study aims to assess the impact of gender diversity on firm performance using the same model for two periods. The multivariate model includes firm performance as the dependent variable and board diversity and control variables as the independent variables:

$$
\text { FirmPerformance }_{i t}=\beta_{0}+\beta_{1} \text { Female }_{i t}+\beta_{2} \text { Foreign }_{i t}+\sum \beta_{n} \text { Controls }+\varepsilon_{i t}
$$

The dependent variable (Firm Performance) is captured through several indicators using accounting measures, including return on assets $(R O A)$, return on equity $(R O E)$ and return on invested capital $(R O I C)$, providing evidence regarding firms' past performance. ROA has been the most commonly used measure of firm performance in the literature (e.g., Easterwood et al. 2012; Erhardt et al. 2003; Shrader et al. 1997). In addition to ROA, ROE and ROIC are used to measure firm performance. The market-to-book ratio $(M T B)$ is also used to measure firms' market performance. Measuring firm performance throughout the literature has been performed through two measures: accounting and market performance (e.g., Ararat and Yurtoğlu 2021; Mertzanis et al. 2019).

The main board diversity measure is gender diversity, which is measured by the ratio of the number of women to the total number of board members (Female). The authors also control for national diversity, which is operationalised by the ratio of foreigners (Foreign). In all models, several firm characteristic measures (leverage, firm size and audit-firm size) are added as control variables. All variable definitions and data sources are detailed in Table 2.

\subsection{Sample}

The sample includes the top 50 "most active" (a term used by the Egyptian Exchange (EGX) to represent trading volume) companies listed on the EGX (EGX 50). The Disclosure Department at EGX published data on EGX 50 in a so-called "Disclosure Book" which included board structure information that was only available to firms included in this publication. The Disclosure Book was published for 2005 through 2011, which was the last year of its issuance. Board structure data was retrieved manually for seven years (2005-2011) from the Disclosure Book for EGX 50 companies. Data was manually collected for the years 2012-2014 from other publicly available sources, including companies' annual reports and websites. Data on firm performance, and on the financial characteristics used as control variables, were collected from Thomson Reuters. 
Table 2. Definitions of variables.

\begin{tabular}{|c|c|c|c|}
\hline Category & $\begin{array}{l}\text { Abbreviation Used } \\
\text { in Statistics }\end{array}$ & Variable & Measurement \\
\hline \multirow[t]{3}{*}{ Firm performance } & ROIC & Return on invested capital & $\begin{array}{c}\text { (Net income }- \text { bottom line }+((\text { interest expense on } \\
\text { debt-interest capitalised }) \times(1-\text { tax rate }))) / \text { average } \\
\text { of last year's and current year's total assets } \times 100 \\
(\text { net income }- \text { bottom line }+((\text { interest expense on } \\
\text { debt }- \text { interest capitalised }) \times(1-\text { tax } \\
\text { rate }))) / \text { average of last year's and current year's } \\
(\text { total capital }+ \text { short-term debt and current portion } \\
\text { of long-term debt }) \times 100\end{array}$ \\
\hline & $\mathrm{ROE}$ & Return on equity & $\begin{array}{c}\text { (Net income }- \text { bottom line }- \text { preferred dividend } \\
\text { requirement)/average of last year's and current } \\
\text { year's common equity } \times 100\end{array}$ \\
\hline & MTB & Market-to-book value & $\begin{array}{l}\text { Market value of ordinary (common) equity/balance } \\
\text { sheet value of ordinary (common) equity in company }\end{array}$ \\
\hline \multirow[b]{2}{*}{ Independent variables } & Female & Female BOD (board of directors) & $\begin{array}{l}\text { Number of female board members/total number of } \\
\text { board members }\end{array}$ \\
\hline & Foreign & Foreign BOD & $\begin{array}{c}\text { Number of foreign board members/total number of } \\
\text { board members }\end{array}$ \\
\hline \multirow{3}{*}{ Control variables } & Firm Size & Total assets & Log of total assets \\
\hline & Auditor Type & Auditor type & $\begin{array}{c}1=\text { Audited by a Big } 4 \\
0=\text { Audited by a non-Big } 4\end{array}$ \\
\hline & Leverage & Total debt $\%$ common equity & $\begin{array}{l}\text { (Long-term debt }+ \text { short-term debt }+ \text { current portion } \\
\text { of long-term debt)/common equity } \times 100\end{array}$ \\
\hline
\end{tabular}

This table explains the main variables used in the empirical analysis and how they were measured. Source: Firm performance and control variables were retrieved from Thomson Reuters database. Independent variables were retrieved from the 'Disclosure Book' published by EGX, companies' annual reports, and companies' websites.

As the authors aimed to check the outcome of the regime change occurring in 2011 on board structure, and its role in predicting firm performance, data for 2012-2014 was collected for the same companies that were listed on EGX 50 during 2005-2011. Checking the number of companies with full datasets for the 10-year period (2005-2014) after removing companies with missing data resulted in 311 firm-year observations for 2005-2011 (pre-2011) and 88 observations for 2012-2014 (post-2011).

\subsection{Descriptive Statistics and Univariate Analysis}

Descriptive statistics of the main variables of interest before and after 2011 are provided in Table 3. The means of all performance measures, including ROA, ROE, ROIC and MTB decreased by almost half post-2011, indicating the instability in the economy post-2011. Table 3 also shows the similarity in the board structure variables (percentage of females on the board and percentage of foreign directors) in the two periods under study. Descriptive statistics for firm characteristics (size of audit firm, firm size and leverage) are also reported in Table 3, which reveals that there was a decrease in debt as measured by leverage.

The percentage of females on the board varied between $0 \%$ and $50 \%$ post-2011, and between $0 \%$ and $45 \%$ pre-2011. On average, female representation on corporate boards increased from $9 \%$ to $11 \%$ after the revolution, with median values of $7.69 \%$ and $9.55 \%$ before and after the revolution, respectively. Therefore, the descriptive statistics show that there was an increase in the presence of females on corporate boards after the revolution. The authors argue that the figures are still low, but the increase is significant; therefore, any changes in the impact of women on boards can be attributed not to approaching a critical mass, but to changing board culture and attitudes towards women that enabled women to contribute. 
Table 3. Descriptive statistics.

\begin{tabular}{|c|c|c|c|c|c|c|c|c|c|c|c|c|}
\hline \multirow{2}{*}{ Variable } & \multicolumn{6}{|c|}{ Pre-2011 } & \multicolumn{6}{|c|}{ Post-2011 } \\
\hline & Observations & Mean & Median & SD & Minimum & Maximum & Observations & Mean & Median & SD & Minimum & Maximum \\
\hline ROA & 311 & 9.41 & 7.59 & 11.05 & -25.89 & 107.58 & 88 & 4.95 & 3.12 & 8.40 & -13.20 & 34.69 \\
\hline $\mathrm{ROE}$ & 311 & 18.03 & 15.16 & 23.04 & -91.87 & 161.54 & 88 & 7.59 & 6.32 & 14.92 & -25.66 & 62.72 \\
\hline ROIC & 311 & 13.81 & 11.33 & 16.59 & -90.51 & 124.39 & 88 & 7.94 & 5.80 & 13.27 & -15.53 & 62.73 \\
\hline МТВ & 291 & 2.70 & 1.78 & 3.16 & 0.27 & 24.85 & 78 & 1.36 & 0.98 & 1.21 & 0.29 & 8.06 \\
\hline Female & 311 & 9.22 & 7.69 & 10.46 & 0.00 & 45.45 & 88 & 10.92 & 9.55 & 11.69 & 0.00 & 50.00 \\
\hline Foreign & 311 & 6.29 & 0.00 & 15.16 & 0.00 & 90.91 & 88 & 8.33 & 0.00 & 20.48 & 0.00 & 90.91 \\
\hline $\begin{array}{l}\text { Auditor } \\
\text { Type }\end{array}$ & 311 & 0.56 & 1.00 & 0.50 & 0.00 & 1.00 & 88 & 0.60 & 1.00 & 0.49 & 0.00 & 1.00 \\
\hline Firm Size & 311 & 14.71 & 14.63 & 1.65 & 10.87 & 18.37 & 88 & 14.37 & 14.11 & 1.68 & 11.11 & 18.03 \\
\hline Leverage & 311 & 57.25 & 22.52 & 84.61 & 0.00 & 644.02 & 88 & 43.85 & 16.61 & 75.88 & 0.00 & 397.76 \\
\hline
\end{tabular}

This table presents summary statistics on the variables used in the empirical analysis. All variables are defined in Table 2. 
The percentage of foreign directors ranged between $0 \%$ and $90 \%$, with means of $6.29 \%$ and $8.33 \%$ for the pre-2011 and post-2011 periods, respectively, whereas the median was $0.00 \%$ in both periods. These figures demonstrate a large variation between firms in terms of their percentage of foreign directors.

Table 3 also shows that around $60 \%$ of the sampled firms were audited by one of the Big 4 audit firms post-2011, consistent with an influential belief that large accounting firms imply better quality of reported financial statements. Firm size shows relatively limited variation. This reflects that the sample consists of the most liquid and largest firms before 2011. On the other hand, debt level (leverage) shows high variation, with a range between 0 and 644 and a mean (median) of 57.25 (22.52) pre-2011, whereas the variation decreased drastically after the revolution to between 0 and 398, with a mean (median) of 43.85 (16.61).

Table 4 presents correlations for the main variables of interest. For assurance, Spearman's non-parametric coefficients in Panel A and Pearson's parametric coefficients in Panel B are both reported. The two panels in Table 4 report the coefficients pre-2011 and post-2011 below and above the diagonal, respectively. The correlations between the independent variables are not significant (below 0.7), and thus do not appear to pose multicollinearity issues.

Table 4. Correlation analysis.

\begin{tabular}{|c|c|c|c|c|c|c|c|c|c|}
\hline \multicolumn{10}{|c|}{ Panel A: Spearman's Correlations } \\
\hline Variable & ROA & ROIC & ROE & МТВ & Female & Foreign & $\begin{array}{c}\text { Auditor } \\
\text { Type }\end{array}$ & Firm Size & Leverage \\
\hline ROA & 1.000 & $0.920 * * *$ & $0.865^{* * *}$ & $0.363^{* * *}$ & 0.154 & 0.124 & 0.114 & -0.112 & $-0.254^{* *}$ \\
\hline ROIC & $0.870^{* * *}$ & 1.000 & $0.963^{* * *}$ & $0.409 * * *$ & 0.094 & 0.150 & $0.206^{*}$ & 0.012 & $-0.245^{* *}$ \\
\hline ROE & $0.832 * * *$ & $0.943^{* * *}$ & 1.000 & $0.363^{* * *}$ & 0.109 & 0.086 & 0.185 * & 0.006 & -0.250 ** \\
\hline МТВ & $0.352 * * *$ & $0.469^{* * *}$ & $0.480 * * *$ & 1.000 & -0.037 & 0.120 & $0.234^{* *}$ & -0.128 & -0.146 \\
\hline Female & -0.023 & -0.036 & -0.086 & -0.043 & 1.000 & 0.024 & $-0.281^{* * *}$ & -0.203 * & $-0.281^{* * *}$ \\
\hline Foreign & 0.072 & $0.182 * * *$ & $0.217^{* * *}$ & $0.177^{* * *}$ & -0.007 & 1.000 & $0.217 * *$ & $0.347^{* * *}$ & 0.061 \\
\hline $\begin{array}{l}\text { Auditor } \\
\text { Type }\end{array}$ & -0.066 & -0.028 & -0.010 & 0.081 & $-0.154^{* * *}$ & $0.412^{* * *}$ & 1.000 & 0.172 & $0.245^{* *}$ \\
\hline Firm Size & -0.043 & 0.084 & $0.162 * * *$ & 0.091 & $-0.160 * * *$ & $0.468^{* * *}$ & $0.350 * * *$ & 1.000 & $0.447^{* * *}$ \\
\hline Leverage & -0.075 & $-0.105 *$ & 0.072 & $0.146^{* *}$ & -0.058 & $0.282^{* * *}$ & $0.243^{* * *}$ & $0.381^{* * *}$ & 1.000 \\
\hline \multicolumn{10}{|c|}{ Panel B: Pearson's Correlations } \\
\hline Variable & ROA & ROIC & ROE & МТВ & Female & Foreign & $\begin{array}{l}\text { Auditor } \\
\text { Type }\end{array}$ & Firm Size & Leverage \\
\hline $\mathrm{ROA}$ & 1 & $0.947^{* * *}$ & $0.906^{* * *}$ & $0.439 * * *$ & 0.159 & 0.117 & 0.087 & -0.071 & $-0.180 *$ \\
\hline ROIC & $0.827 * * *$ & 1 & $0.959 * * *$ & $0.434 * * *$ & 0.127 & 0.133 & 0.104 & -0.018 & $-0.196 *$ \\
\hline $\mathrm{ROE}$ & $0.787 * * *$ & $0.895^{* * *}$ & 1 & $0.301^{* * *}$ & 0.143 & 0.095 & 0.081 & -0.031 & $-0.305^{* * *}$ \\
\hline МТВ & $0.111 *$ & $0.282 * * *$ & $0.329 * * *$ & 1 & 0.030 & 0.179 & 0.184 & -0.016 & $0.280 * *$ \\
\hline Female & -0.065 & -0.082 & $-0.130 * *$ & -0.060 & 1 & 0.150 & $-0.285^{* * *}$ & $-0.202 *$ & -0.078 \\
\hline Foreign & 0.077 & $0.163^{* * *}$ & $0.210 * * *$ & 0.085 & 0.023 & 1 & $0.252 * *$ & $0.243^{* *}$ & 0.023 \\
\hline $\begin{array}{l}\text { Auditor } \\
\text { Type }\end{array}$ & -0.019 & -0.042 & 0.016 & -0.072 & $-0.175^{* * *}$ & $0.352 * * *$ & 1 & $0.236^{* *}$ & $0.215^{* *}$ \\
\hline Firm Size & 0.041 & 0.075 & $0.152 * * *$ & 0.022 & $-0.155^{* * *}$ & $0.391^{* * *}$ & $0.360 * * *$ & 1 & $0.360 * * *$ \\
\hline Leverage & -0.065 & -0.063 & $0.122 * *$ & $0.133^{* *}$ & -0.020 & $0.160^{* * *}$ & $0.173^{* * *}$ & $0.280 * * *$ & 1 \\
\hline
\end{tabular}

Table 4 shows that the percentages of females and foreign directors on the board do not seem to be correlated before or after 2011. This table shows correlation coefficients between all the variables used in the empirical analysis. Panel A shows the Spearman's correlations and Panel B shows the Pearson's correlations. Pre-2011 correlations are provided below the diagonal, whereas post-2011 correlations are above. All variables are defined in Table $2 .{ }^{* * *}$ correlation is significant at the $1 \%$ level; ${ }^{* *}$ correlation is significant at the $5 \%$ level; ${ }^{*}$ correlation is significant at the $10 \%$ level.

\section{Empirical Results}

First, an OLS regression is run with all observations to investigate the association between the ratios of female and foreign directors and firm performance during the period from 2005 to 2014. The results of this regression are reported in Table 5. Table 5 shows that, on average, there is no significant association between the ratio of female board members and firm performance, whereas the presence of foreign directors has a significant and positive relationship with firm performance for the same period, when all observations for the total period under investigation are pooled in the regression. These results follow 
Detthamrong et al. (2017) reporting no significant impact of board gender diversity on firm performance in Thailand. In addition, the positive association between the presence of foreign board members and firm performance follows results reported by Guney et al. (2020) in East African frontier markets.

Table 5. Pooled OLS.

\begin{tabular}{|c|c|c|c|c|}
\hline Variable & $\begin{array}{c}(1) \\
\text { ROA }\end{array}$ & $\begin{array}{c}(2) \\
\text { ROE }\end{array}$ & $\begin{array}{c}\text { (3) } \\
\text { ROIC }\end{array}$ & $\begin{array}{c}(4) \\
\text { MTB }\end{array}$ \\
\hline Female & $\begin{array}{c}0.019 \\
(0.389)\end{array}$ & $\begin{array}{c}-0.062 \\
(-1.197)\end{array}$ & $\begin{array}{c}-0.013 \\
(-0.245)\end{array}$ & $\begin{array}{l}-0.104 \text { * } \\
(-1.915)\end{array}$ \\
\hline Foreign & $\begin{array}{c}0.032 \\
(0.664)\end{array}$ & $\begin{array}{l}0.112 \text { ** } \\
(2.120)\end{array}$ & $\begin{array}{l}0.119 * * \\
(2.199)\end{array}$ & $\begin{array}{c}0.150^{* * *} \\
(2.690)\end{array}$ \\
\hline Auditor Type & $\begin{array}{c}0.015 \\
(0.304)\end{array}$ & $\begin{array}{c}-0.079 \\
(-1.461)\end{array}$ & $\begin{array}{c}-0.075 \\
(-1.360)\end{array}$ & $\begin{array}{c}-0.220^{* * *} \\
(-3.764)\end{array}$ \\
\hline Firm Size & $\begin{array}{c}0.197 * * * \\
(3.594)\end{array}$ & $\begin{array}{c}0.155^{* * *} \\
(2.624)\end{array}$ & $\begin{array}{c}0.167^{* * *} \\
(2.754)\end{array}$ & $\begin{array}{c}-0.085 \\
(-1.366)\end{array}$ \\
\hline Leverage & $\begin{array}{c}-0.207^{* * *} \\
(-4.508)\end{array}$ & $\begin{array}{l}-0.083 * \\
(-1.665)\end{array}$ & $\begin{array}{c}-0.195^{* * *} \\
(-3.838)\end{array}$ & $\begin{array}{c}0.071 \\
(1.357)\end{array}$ \\
\hline Observations & 399 & 399 & 399 & 399 \\
\hline Adjusted R2 & 0.367 & 0.261 & 0.225 & 0.244 \\
\hline Year fixed effect & Yes & Yes & Yes & Yes \\
\hline $\begin{array}{l}\text { Industry } \\
\text { dummy }\end{array}$ & Yes & Yes & Yes & Yes \\
\hline
\end{tabular}

Next, a regression to test the hypothesis is run. The main test was an OLS regression, as described in Equation (1), across two different subsamples (time periods): before and after 2011. The results of this test are shown in Table 6. The results show that none of the dependent variables is significantly associated with the presence of women on the board (except for ROE at the 10\% level) before 2011. However, the presence of women on the board appears to have been a positive and significant determinant of most of the firm performance proxies (ROA, ROE and ROIC) after 2011, with models generally more capable of explaining variations in firm performance-except for $M T B$, which changes its direction from negative to positive, but remains insignificant. This shows that in the post-2011 period, overall, the presence of women on boards led to better performance of firms in all performance measures. ${ }^{2}$ There are two possible explanations for the insignificant relationship between the presence of women on the board and $M T B$ values. First, capital markets were still dysfunctional, with a significant capital flight in the post-2011 period. Second, the post-2011 period in the sample is characterised by increased political uncertainty. Models of political risk predict that increases in political uncertainty will lead to a decrease in stock prices (Liu et al. 2017). Thus, the relationship between firm-level performance and MTB ratio is more likely to be influenced by the witnessed decrease in stock prices, which will lead to a decrease in the MTB ratio.

The results confirm that the relationship between board diversity and firm performance changes in the event of an external shock and reflects changes in the board dynamics in response to changes in the competitive environment. These results resemble the findings of Yang and Zhao (2014), who reported a conditional effect of CEO duality on performance in the event of an exogenous shock. Findings also report that different diversity attributes are more likely to have a positive influence on firm performance, and that woman directors may make unique positive contributions, while foreign directors have no effect. Table 6 also shows that firm size and leverage are significant determinants of firm performance before and after 2011, while the relationship between leverage and various performance proxies is negative and significant before and after 2011. Interpretation of these findings is 
that the revolution, as an exogenous shock to the Egyptian market, did not influence the relationship between firm fundamentals and firm performance. Results also support the notion that the macroeconomic and political environment can affect the quality of corporate governance and boards' role in emerging economies (Ugur and Ararat 2006).

Table 6. Pre- and post-revolution: board diversity.

\begin{tabular}{|c|c|c|c|c|c|c|c|c|}
\hline \multirow{3}{*}{ Variable } & \multicolumn{4}{|c|}{ Pre-2011 } & \multicolumn{4}{|c|}{ Post-2011 } \\
\hline & (1) & (2) & (3) & (4) & (5) & (6) & (7) & (8) \\
\hline & ROA & ROE & ROIC & МТВ & ROA & ROE & ROIC & МТВ \\
\hline \multirow[t]{2}{*}{ Female } & -0.001 & $-0.100 *$ & -0.04 & -0.095 & $0.303^{* *}$ & $0.381^{* * *}$ & $0.305^{* *}$ & 0.173 \\
\hline & $(-0.017)$ & $(-1.665)$ & $(-0.641)$ & $(-1.484)$ & -2.317 & -2.999 & -2.221 & -1.406 \\
\hline \multirow[t]{2}{*}{ Foreign } & 0.071 & $0.178^{* * *}$ & $0.185^{* * *}$ & $0.134^{* *}$ & $-0.206^{* *}$ & $-0.224 *$ & -0.182 & -0.069 \\
\hline & (1.199) & -2.847 & -2.884 & -1.985 & $(-1.703)$ & $(-1.901)$ & $(-1.430)$ & $(-0.607)$ \\
\hline \multirow{2}{*}{$\begin{array}{l}\text { Auditor } \\
\text { Type }\end{array}$} & 0.013 & -0.098 & -0.091 & $-0.239^{* * *}$ & 0.126 & 0.109 & 0.098 & 0.034 \\
\hline & $(0.223)$ & $(-1.528)$ & $(-1.388)$ & $(-3.414)$ & -0.995 & -0.885 & -0.73 & -0.284 \\
\hline \multirow[t]{2}{*}{ Firm Size } & $0.134^{* *}$ & 0.114 & $0.125 *$ & -0.073 & $0.350 * *$ & $0.348^{* * *}$ & $0.320 * *$ & 0.001 \\
\hline & $(2.018)$ & -1.626 & -1.727 & $(-0.979)$ & -2.626 & -2.687 & -2.283 & -0.005 \\
\hline \multirow{2}{*}{ Leverage } & $-0.185^{* * *}$ & -0.006 & $-0.156^{* * *}$ & $0.102 *$ & $-0.224 *$ & $-0.298 *$ & $-0.232 *$ & -0.033 \\
\hline & $(-3.384)$ & $(-0.107)$ & $(-2.608)$ & -1.659 & $(-1.816)$ & $(-2.486)$ & $(-1.789)$ & $(-0.261)$ \\
\hline Observations & 311 & 311 & 311 & 291 & 88 & 88 & 88 & 78 \\
\hline Adjusted R2 & 0.285 & 0.196 & 0.151 & 0.145 & 0.285 & 0.324 & 0.21 & 0.447 \\
\hline $\begin{array}{l}\text { Industry } \\
\text { Dummies }\end{array}$ & Yes & Yes & Yes & Yes & Yes & Yes & Yes & Yes \\
\hline
\end{tabular}

${ }^{*} p<0.1 ;{ }^{* *} p<0.05 ;{ }^{* *} p<0.01$. This table presents the results of the re-estimation of the OLS regression specified in Equation (1) across two subsamples. The first subsample (pre-2011) includes firm-year observations of the pre-2011 period, while the second subsample (post-2011) includes firm-year observations of the post-2011 period. Columns (1) and (5) employ ROA as the dependent variable, Columns (2) and (6) employ ROE as the dependent variable, Columns (3) and (7) employ ROIC as the dependent variable, and Columns (4) and (8) employ MTB as the dependent variable. All variables are defined in Table 2.

In summary, findings show that after a significant change in the role of women due to the political and social changes taking place in Egypt after 2011, an unprecedented positive and significant relationship between board gender diversity and firm performance can be observed. This evidence provides significant support for discourse seeking to promote the presence of women on corporate boards and, unlike other studies, shows that the importance of gender diversity could be even more significant during times of turmoil and a lack of economic stability.

\section{Conclusions}

Despite the growing literature on board diversity in corporate boards, evidence has been mixed on the association between various diversity attributes and firm performance. This has largely been attributed to contextual differences and endogeneity issues. In this paper, the authors employ a novel approach that mitigates the endogeneity challenge in the setting of a radical change in the environment firms face benefiting from an external shock. Findings show that gender diversity is a significant determinant of firm performance when firms' political and economic environment becomes complex and unpredictable. Based on the contradictory results for directors' nationality diversity, it is reported that not all diversity attributes function in the same way and it is suggested that researchers should be careful about using holistic diversity measures. The results provide further support to the argument that women can make a unique contribution to firm performance during difficult times based on their different cognitive abilities compared to men. They may also contribute more when their contribution is valued more.

The study is subject to the following caveats. First, results may not apply to other countries, since each emerging economy varies in a different way and the authors chose an emerging economy, Egypt, as the current context. Second, the sample size is relatively small limiting the number of control variables that the authors could use in the estimations. Finally, the authors acknowledge that controlling for board independence is expected to improve the explanatory power of the models and reduce the potential bias of omitting 
a correlated variable. However, this variable is not available for the sampled firm-year observations since the classification was introduced in Egypt after the study period.

Accordingly, we believe that this study has academic implications through supporting future research as follows. First, it lays the groundwork for future research to explore how the relation between board diversity attributes and firm performance could be affected by changes in the macroeconomic (country-level) context, by employing a natural or quasinatural experiment as per this study. Second, the increased frequency of drastic changes in a political environment offers opportunities for using new lenses in governance research. Additionally, future research on the moderating effect of board dynamics and board culture on the relation between gender diversity and performance in the presence of an exogenous shock would provide insights into the channels through which the benefits of diversity may materialize. In addition, these findings can provide policy makers, regulators, investors and other stakeholders with a broader perspective that could help assess the relationship between board diversity and firm performance in listed companies in Egypt or in other emerging markets. Finally, these findings support the importance of women's role in society, especially during periods of uncertainty and when external shocks are occurring in the economy.

Author Contributions: Conceptualization, M.A. and N.S.; Methodology, M.E.-H. and N.S.; Software, M.E.-H.; Validation, M.E.-H.; Formal Analysis, M.E.-H.; Investigation, N.S.; Resources, N.S.; Data Curation, N.S.; Writing-Original Draft Preparation, M.A., M.E.-H. and N.S.; Writing-Review \& Editing, M.A., M.E.-H., A.L. and N.S.; Visualization, M.A., M.E.-H., A.L. and N.S.; Supervision, M.A., M.E.-H., A.L. and N.S.; Project Administration, M.A., M.E.-H., A.L. and N.S. All authors have read and agreed to the published version of the manuscript.

Funding: This research received no external funding.

Institutional Review Board Statement: Not applicable.

Informed Consent Statement: Not applicable.

Data Availability Statement: Not applicable.

Conflicts of Interest: The authors declare no conflict of interest.

\section{Notes}

1 Egypt had a quota for women in parliament from 2010 to 2012. The quota was abolished in 2012 when the constitution was changed by the Islamist government. It was reinstated in the 2015 constitution. Further details about the constitution articles are available at: https:/ / www.idea.int/data-tools/data/gender-quotas/country-view/100/35 (accessed on 25 March 2021).

2 In untabulated regressions, the authors examined whether the period post-2011 was associated with firm performance. The coefficient of the dummy variable post-2011 is negative and significant at the $1 \%$ level.

\section{References}

Abdel-Meguid, Ahmed. 2021. Corporate governance in Egypt: The landscape, the research, and future directions. Corporate Ownership \& Control 18: 296-306.

Aboud, Ahmed, and Ahmed Diab. 2019. The financial and market consequences of environmental, social and governance ratings-The implications of recent political volatility. Sustainability Accounting, Management and Policy Journal 10: 498-520. [CrossRef]

Acemoglu, Daron, Tarek A. Hassan, and Ahmed Tahoun. 2018. The power of the street: Evidence from Egypt's Arab Spring. Review of Financial Studies 31: 1-42. [CrossRef]

Adams, Renée B., and Daniel Ferreira. 2009. Women in the boardroom and their impact on governance and performance. Journal of Financial Economics 94: 291-309. [CrossRef]

Ahmadi, Ali, Nejia Nakaa, and Abdelfettah Bouri. 2018. Chief Executive Officer attributes, board structures, gender diversity and firm performance among French CAC 40 listed firms. Research in International Business and Finance 44: 218-26. [CrossRef]

Al-Wahaidy, Fatima. 2017. Can Gender Quotas Contribute to Closing Gender Gap. Egypt Today 2nd of November 2017. Available online: http:/ / www.egypttoday.com/Article/2/30561/Can-gender-quotas-contribute-to-closing-gender-gap (accessed on 1 July 2021).

Al-Yahyee, Khamis Hamed, Ahmed Khamis Al-Hadi, and Syed Mujahid Hussain. 2017. Market risk disclosures and board gender diversity in Gulf Cooperation Council (GCC) firms. International Review of Finance 17: 645-58. [CrossRef]

Ararat, Melsa, and Burcin. B. Yurtoğlu. 2021. Female Directors, Board Committees and Firm Performance: Time-Series Evidence from Turkey. Emerging Markets Review 48: 100768. [CrossRef] 
Ararat, Melsa, Stijn Claessens, and Burcin Yurtoglu. 2021. Corporate governance in emerging markets: A selective review and an agenda for future research. Emerging Markets Review 48: 100767. [CrossRef]

Becker, Gary. 1957. The Economics of Discrimination, 2nd ed. Chicago: University of Chicago Press.

Carter, David A., Betty J. Simkins, and W. Gary Simpson. 2003. Corporate governance, board diversity, and firm value. Financial Review 38: 33-53. [CrossRef]

Choukeir, Cedric. 2013. Social Inclusion, Democracy and Youth in the Arab Region. Beirut: UNESCO.

Cumming, Douglas, Tak Yan Leung, and Oliver Rui. 2015. Gender diversity and securities fraud. Academy of Management Journal 58: 1572-93. [CrossRef]

Detthamrong, Umawadee, Nongnit Chancharata, and Chaiporn Vithessonthic. 2017. Corporate governance, capital structure and firm performance: Evidence from Thailand. Research in International Business and Finance 42: 689-709. [CrossRef]

Dillard, Jesse M., and MaryAnn Reynolds. 2008. Green owl and the corn maiden. Accounting, Auditing and Accountability Journal 21: 556-79. [CrossRef]

Easterwood, John C., Özgür Ş. İnce, and Charu G. Raheja. 2012. The evolution of boards and CEOs following performance declines. Journal of Corporate Finance 18: 727-44. [CrossRef]

Egyptian Institute of Directors (EIoD). 2016. The Egyptian Corporate Governance Code. Cairo: Egyptian Financial Supervisory Authority.

El-Behary, Hend. 2016. Women's Representation in New Parliament Highest in Egypt's History. Egypt Independent 5th of Janurary 2016. Available online: https:/ / ww.egyptindependent.com/women-s-representation-new-parliament-highest-egypt-s-history (accessed on 1 April 2021).

Erhardt, Niclas L., James D. Werbel, and Charles B. Shrader. 2003. Board of director diversity and firm financial performance. Corporate Governance: An International Review 11: 102-11. [CrossRef]

Farag, Hisham, and Christine Mallin. 2017. Board diversity and financial fragility: Evidence from European banks. International Review of Financial Analysis 49: 98-112. [CrossRef]

Ferreira, Daniel, Edith Ginglinger, Marie-Aude Laguna, and Yasmine Skalli. 2020. Closing the Gap: Board Gender Quotas and Hiring Practices. Working Paper. Brussels: European Corporate Governance Institute.

Fracolli, Erin. 2017. Women and Quotas in Egypt's Parliament. The Tahrir Institute for Middle East Policy. Available online: https: / / timep.org/commentary/women-and-quotas-in-egypts-parliament/ (accessed on 1 October 2018).

Francoeur, Claude, Réal Labelle, and Bernard Sinclair-Desgagné. 2008. Gender diversity in corporate governance and top management. Journal of Business Ethics 81: 83-95. [CrossRef]

Giannetti, Mariassunta, and Tracy Yue Wang. 2021. Public Attention to Gender Equality and Board Gender Diversity. Working Paper. Brussels: European Corporate Governance Institute.

Guney, Yilmaz, Ahmet Karpuz, and Gabriel Komba. 2020. The effects of board structure on corporate performance: Evidence from East African frontier markets. Research in International Business and Finance 53: 101222. [CrossRef]

Hasan, Mozn. 2015. Women's Rights in the Aftermath of Egypt's Revolution. EU Spring Working Paper Series; Working Paper 5. EU Spring Project. Available online: http:/ / aei.pitt.edu/67178/1/euspring_paper_5_womans_rights_in_egypt.pdf (accessed on 7 August 2021).

Hermalin, Benjamin, and Michael Weisbach. 2003. Board of Directors as an endogenously determined institution: A survey of the economic literature. Economic Policy Review 9: 7-26.

Kahane, Leo, Neil Longley, and Robert Simmons. 2013. The effects of coworker heterogeneity on firm-level output: Assessing the impacts of cultural and language diversity in the national hockey league. Review of Economics and Statistics 95: 302-14. [CrossRef]

Kirsch, Anja. 2018. The gender composition of corporate boards: A review and research agenda. The Leadership Quarterly 29: 346-64. [CrossRef]

Lau, Dora Chi-sun, and John Keith Murninghan. 1998. Demographic diversity and faultlines: The compositional dynamics of organizational groups. Academy of Management Review 23: 325-40. [CrossRef]

Liu, Laura Xiaolei, Haibing Shu, and K. C. John Wei. 2017. The impacts of political uncertainty on asset prices: Evidence from the Bo scandal in China. Journal of Financial Economics 125: 28-310. [CrossRef]

Mertzanis, Charilaos, Mohamed A. K. Basuony, and Ehab K. A. Mohamed. 2019. Social institutions, corporate governance and firm-performance in the MENA region. Research in International Business and Finance 48: 75-96. [CrossRef]

Mostafa, Dalia Said. 2015. Introduction: Egyptian women, revolution, and protest culture. Journal for Cultural Research 19: 118-29. [CrossRef]

Naber, Nadine. 2011. Women and the Arab Spring: Human rights from the ground up. Journal of the International Institute of the University of Michigan 1: 11-13.

National Council for Women. 2017. National Strategy for the Empowerment of Egyptian Women 2030. Available online: http:/ /ncw. gov.eg/wp-content/uploads/2018/02/ final-version-national-strategy-for-the-empowerment-of-egyptian-women-2030.pdf (accessed on 25 July 2018).

New York Times. 2014. Timeline of Turmoil in Egypt from Mubarak and Morsi to Sisi. Available online: https://archive.nytimes.com/ www.nytimes.com/interactive/2013/07/02/world/middleeast/03egypt-timeline-morsi.html\#/\#time259_8831 (accessed on 30 August 2020).

Nikolaev, Valeri, and Laurence Van Lent. 2005. The endogeneity bias in the relation between cost-of-debt capital and corporate disclosure policy. European Accounting Review 14: 677-724. [CrossRef] 
Organisation for Economic Co-operation and Development (OECD). 2010. Business Climate Development Strategy. Paris: MENA-OECD Investment Program.

Ottaway, Marina, and Amr Hamzawy. 2011. Protest Movements and Political Change in the Arab World. Washigngton: Carnegie Endowment for International Peace.

Oware, Kofi Mintah, and Thathaiah Mallikarjunappa. 2021. Financial performance and gender diversity: The moderating and mediating effect of CSR disclosure and expenditure of listed firms in India. Vision 53: 101222.

Özbilgin, Mustafa, Ahu Tatli, Gulce Ipek, and Mohammed Sameer. 2016. Four approaches to accounting for diversity in global organisations. Critical Perspectives on Accounting 35: 88-99. [CrossRef]

Post, Corinne, and Kris Byron. 2015. Women on boards and firm financial performance: A meta-analysis. Academy of Management Journal 58: 1546-71. [CrossRef]

Ramadan, Maha Mohamed, and Mostafa Kamal Hassan. 2021. Board gender diversity, governance and Egyptian listed firms' performance. Journal of Accounting in Emerging Economies. [CrossRef]

Reguera-Alvarado, Nuria, Pilar de Fuentes, and Joaquina Laffarga. 2017. Does board gender diversity influence financial performance? Evidence from Spain. Journal of Business Ethics 141: 337-50. [CrossRef]

Reuters. 2018. Update 1-Egypt issues $\$ 4$ Billion in Eurobonds. Available online: https:/ /www.reuters.com/article/egypt-eurobondsidAFL8N1Q425Y (accessed on 7 August 2021).

Saleh, Heba. 2017. Egypt Attracts Foreign Investment as Currency Falls. Financial Times 22nd of March 2017. Available online: https: / www.ft.com/content/083a15cc-e248-11e6-9645-c9357a75844a (accessed on 30 December 2018).

Shrader, Charles B., Virginia B. Blackburn, and Paul Iles. 1997. Women in management and firm financial performance: An exploratory study. Journal of Managerial Issues 9: 355-72.

Sinclair, Amanda. 1998. Doing Leadership Differently: Gender, Power and Sexuality in a Changing Business Culture. Carlton: Melbourne University Press.

Smith, Nina, Valdemar Smith, and Mette Verner. 2006. Do women in top management affect firm performance? A panel study of 2500 Danish firms. International Journal of Productivity and Performance Management 5 5: 569-93. [CrossRef]

The Economist. 2016. After the Arab Spring. Available online: http:/ /www.economist.com/news/leaders/21703374-repression-andincompetence-abdel-fattah-al-sisi-are-stoking-next-uprising (accessed on 1 April 2017).

Tremblay, Marie-Soleil, Yves Gendron, and Bertrand Malsch. 2016. Gender on board: Deconstructing the "legitimate" female director. Accounting, Auditing and Accountability Journal 29: 165-90. [CrossRef]

Ugur, Mehmet, and Melsa Ararat. 2006. Does macroeconomic performance affect corporate governance? Evidence from Turkey. Corporate Governance: An International Review 14: 325-48. [CrossRef]

UN Women and Promundo. 2017. International Men and Gender Equality Survey (IMAGES)—Middle East and North Africa. Available online: https:/ /imagesmena.org/wp-content/uploads/sites/5/2017/05/IMAGES-MENA-Executive-Summary-EN-16May2 017-web.pdf (accessed on 1 August 2021).

Van Knippenberg, Daan, S. Alexander Haslam, and Michael J. Platow. 2007. Unity through diversity: Value-in-diversity beliefs, work group diversity, and group identification. Group Dynamics: Theory, Research, and Practice 11: 207-22. [CrossRef]

Velthouse, Betty, and Yener Kandogan. 2007. Ethics in practice: What are managers really doing? Journal of Business Ethics 70: 151-63. [CrossRef]

World Economic Forum (WEF). 2017. Gender Gap Reports. Available online: http:/ / reports.weforum.org/global-competitivenessreport-2015-2016/economies/\#economy=EGY (accessed on 1 August 2021).

Wintoki, M. Babajide, James Linck, and Jeffry Netter. 2012. Endogeneity and the dynamics of internal corporate governance. Journal of Financial Economics 105: 581-606. [CrossRef]

World Bank. 2017. World Development Indicators. Available online: http://databank.worldbank.org/data/reports.aspx?source= world-development-indicators\# (accessed on 1 July 2021).

Yang, Tina, and Shan Zhao. 2014. CEO duality and firm performance: Evidence from an exogenous shock to the competitive environment. Journal of Banking and Finance 49: 534-52. [CrossRef] 